\title{
Foreign Ownership and Long-term Survival
}

\author{
Kronborg, Dorte; Thomsen, Steen
}

Document Version

Final published version

Publication date:

2006

\section{License \\ CC BY-NC-ND}

Citation for published version (APA):

Kronborg, D., \& Thomsen, S. (2006). Foreign Ownership and Long-term Survival.

Link to publication in CBS Research Portal

\section{General rights}

Copyright and moral rights for the publications made accessible in the public portal are retained by the authors and/or other copyright owners and it is a condition of accessing publications that users recognise and abide by the legal requirements associated with these rights.

\section{Take down policy}

If you believe that this document breaches copyright please contact us (research.lib@cbs.dk) providing details, and we will remove access to the work immediately and investigate your claim. 


\title{
Foreign Ownership and Long-term Survival
}

\author{
Dorte Kronborg \\ Center for Statistics \\ Copenhagen Business School \\ Steen Thomsen* \\ Center for Corporate Governance \\ Copenhagen Business School
}

April 21, 2006

\begin{abstract}
Does foreign ownership enhance or decrease a firm's chances of survival? Over the 100 year period 1895-2001 this paper compares the survival of foreign subsidiaries in Denmark to a control sample matched by industry and firm size. We find that foreign-owned companies have a higher survival probability. On average exit risk for domestic companies is 2.3 times higher than for foreign companies. First movers like Siemens, Philips, Kodak, Ford, GM or Goodyear have been active in the country for almost a century. Relative foreign survival increases with company age. However, the foreign survival advantage appears to be eroded by globalization, it decreases over time and disappears at the end of the century.
\end{abstract}

*Corresponding author: Professor, Ph.D., Center for Corporate Governance, Department of International Economics and Management, Copenhagen Business School, Porcelænshaven 23 A Building 65, 2000 Copenhagen F, Denmark, Phone +45 38152590 , Fax +45 38152500, E-mail: st.int@cbs.dk 


\section{Introduction}

How does foreign ownership affect the survival of companies? Does foreign ownership generally improve corporate survival chances by resource transfers from the parent company? Or does it reduce survival because of the liability of foreignness, internal bureaucracy, lower flexibility or other characteristics of foreign ownership? While there have been several studies of the survival of foreign subsidiaries (e.g. Mitchell, Yeung and Shaver, 1994, Shaver, 1995, 1998; Li, 1995; Shaver et al. 1997, 1998, Delios and Beamish 2001, Delios and Beamish 2004, Dhanaraj and Beamish 2004, Chung and Beamish 2005), only a few appear to have compared the survival of foreign-owned and domestic companies (Li and Guisinger, 1991, Pennings et al. 1994, Zaheer, 1995, Zaheer and Mosakowski, 1997, Mata and Portugal, 2002).

This paper examines the survival of foreign subsidiaries in Denmark over the past century compared to domestically owned companies (for convenience we sometimes refer to these companies as "foreign" and "domestic" respectively). Using a unique data source (Green's handbook of Danish Funds and Stocks), which has published a fairly comprehensive register of companies operating in Denmark since 1887, the paper is able to track companies over the 100-year period 1895-2001. Using the same database we are able to construct a matched sample of domestically owned companies in the same industry and size classes.

To illustrate the methodology, one of our observations is Ford Motor Company, which established a European subsidiary in Denmark in 1919 (the second in Europe). This subsidiary which supplied the Nordic and Baltic markets, Poland and Germany was from the very beginning one of the largest manufacturing companies in Denmark producing Ford T, Ford A and later V8 engines such as Anglia as well as tractors. Production was closed down in 1965, but the company continues as a sales and service operation. We match Ford with The United Danish Automobile Manufacturers (De Forenede Danske Automobilfabrikker), a 1918 merger of 3 Danish producers, which produced cars, especially trucks and busses (and later motor trains), until production was closed down in 1957, after which the company began importing foreign brands (e.g. British Triumph). The company was closed in 1993. We register this case as evidence that the foreign company (Ford) survived and survived longer, so far for 81 years (currently 87 ) com- 
pared to 75 years for the domestic control company.

Analyzing this data set foreign subsidiaries are found have a significantly higher survival probability than domestically owned companies. The difference between the two groups is numerically large and robust to control for industry, time period and firm size.

The paper is organized in the usual way. Section 2 considers the theoretical relationship between domestic/foreign ownership and company survival. Section 3 presents the data. Section 4 presents the statistical results. And section 5 concludes.

\section{Theory and Previous Evidence}

The standard theory of the multinational enterprize (Caves 1996, Buckley and Casson 1976, Dunning 1981, Hennart 1991) proposes that foreign direct investment will occur and be successful when ownership, location and internalization advantages exceed the costs of establishing and running foreign subsidiaries (Dunning, 1981). International business activities can in principle be conducted without foreign subsidiaries - by international trade between independent companies, subcontracting of production, licensing etc. But some companies have competitive (ownership) advantages based on firm specific resources that are most effectively exploited by establishing foreign production facilities (internalized) within a multinational corporation. Similar arguments figure prominently in the international business literature as a rationale for establishment of sales subsidiaries rather than independent distributors (Anderson and Gattignon 1986).

The theory predicts that foreign subsidiaries have performance advantages in industries where firm specific resources matter while transaction costs are high, and several empirical studies have supported this hypothesis (Caves 1996). The implication is that foreign subsidiaries will have higher survival rates if their competitive advantage relative to domestic companies exceeds their added costs of operating in a foreign country.

To the ownership and location advantage arguments we must add the 
possible options-like character of foreign direct investment (Kogut and Kutilaka 1994; Mata, 2002). Multinational companies may decide to maintain a presence in a country despite adverse conditions because foreign subsidiaries provide them with valuable options for future expansion. This may improve their survival power relative to that of domestic companies.

Ownership and internalization advantages must be balanced against disadvantages of foreign ownership. Hymer (1960) suggested that multinational companies which establish subsidiaries in a foreign country incur costs because they lack knowledge of business conditions in the host country and because of policy discrimination. These costs can be thought of as the "liability of foreignness" (Zaheer 1995). If foreign parent companies act under a veil of ignorance compared to their host country competitors, they are likely to make more mistakes which could very well result in a higher exit rate. However, it is not evident that foreignness is necessarily a liability in all cases. Mata and Portugal (2002) argue that controlling for the liability of newness new foreign subsidiaries have better survival chances than new domestic ventures because they can draw on the expertise, experience and legitimacy of the parent company. Brannen (2004) documents that foreignness was advantage in for Disneyland Tokyo and suggests that foreign firms may to some extent recontextualise their operations to achieve a better semantic fit with the host country environment.

In addition, the corporate governance of domestic companies differs systematically from that of foreign subsidiaries. Standard agency theory (Jensen and Meckling 1976) predicts that the weight attached to managerial goals (such as size, growth and survival) relative to profitability will decrease with ownership concentration, and foreign parent companies tend to be strong, well-informed owners with high ownership stakes. Boardman et al. (1996) point to the agency argument as a possible explanation for superior profitability in foreign-owned companies. Agency concerns could also lead to a home country preference and discrimination against foreign entities. Closing down or selling off foreign entities may be easier than closing down or selling of entities close to the home office (including of course the top managersown job). Moreover, home country stakeholders may be more influential compared to host country stakeholders. The implication is that companies may adopt a more instrumental view of foreign subsidiaries, which are therefore more likely to be closed down if they do not contribute to shareholder value 
or survival of the parent company.

Altogether, we expect the relative survival rates of foreign and domestic companies to depend on a balance of ownership and internalization advantages against the liability of foreignness and possible home country bias.

As for empirical studies, there have to our knowledge been remarkably few.

Li and Guisinger (1991) conducted the first systematic study comparing the failures of foreign and domestically controlled firms in the US and laid the ground for subsequent work by developing many of the basic ideas. They gathered data on business failures of foreign-controlled firms $(n=85)$ relative to aggregate statistics on the number of foreign subsidiaries and compared these figures to domestic failure rates as calculated by Dun and Bradstreet. The comparison revealed that foreign firms had much lower failure rates, non-financial domestic firms failed more than 8 times more frequently and domestic manufacturing firms failed almost 4 times as frequently as the foreign companies. They interpreted the survival advantage of foreign companies as an indication of ownership advantages as proposed by Dunning (1981). However, given the nature of their data set they were unable to do controlled, multivariate tests, although they did observe that the foreign firms tended to be smaller than the domestic benchmark firms, which indicated that the survival differences were not attributable to size effects. Moreover, it seems natural to inquire whether the low observed failure rates of multinational subsidiaries are attributable to their definition of "failure" (outright bankruptcy or exits involving creditor losses), since foreign multinationals may prefer to close down production in an orderly way rather than risking damage to their reputation by letting subsidiaries go bankrupt as the authors themselves mention ( $\mathrm{Li}$ and Guisinger p. 215-216). Finally, it is not clear that findings from the US will necessarily generalize to other markets. The US is a large, strategic market (which could make foreign parents reluctant to close down subsidiaries because of their option value).

Pennings, Barkema and Douma (1994) reported that 462 "expansions" of large Dutch multinationals failed more often if they were international than if they were domestic. This was established statistically after controlling for mode of expansion (acquisition vs. greenfield), relatedness, experience, 
return on capital and size of the expansion. However, the location effect became insignificant when controlling for firm and period effects. A main contribution of this study is that it analyzed survival from a parent company viewpoint: foreign subsidiaries were compared to domestic subsidiaries and not to independent companies which could be parent companies themselves. In this way the effect of "foreignness" can be distinguished from the effect of being a subsidiary. Another positive feature is the sampling of new ventures which implicitly controls for the liability of newness (Hannan and Carroll 1992, Stinchcombe, 1965). However, both of these strengths also involve limitations. For example, from a policy and strategy viewpoint the relevant choice may be between continuation of a domestic company as an independent ownership unit and being acquired by a foreign multinational, which involves simultaneous changes to subsidiary status and to international ownership. Moreover, there may be a difference between the long and short term evolution of foreign subsidiaries, a point which is emphasized and analyzed in this paper.

Zaheer and Mosakowski (1997) examined the survival rates of 2667 foreign exchange trading rooms from 65 different countries over the 20 year period 1974-1993. They found that foreign trading rooms have higher exit rates, particularly in the first 10-15 years after entry. For example, they indicated that the exit rate of the foreign trading rooms is 0.005 greater than that of their domestically owned counterparts. They interpreted this as evidence of the "liability of foreignness" following a previous study by Zaheer (1995), who estimated that profits per trader were higher in domestic trading rooms. However, for trading rooms with more than 10 years of tenure they found that the difference was reduced to 0.002 . In other words the the liability of foreignness was found to decrease with tenure - for example because the foreign firm learns more about the host country or is better integrated in host country business networks as its tenure and experience increases. Moreover, they find that exit rates of domestic trading rooms increase in the last part of the period which they see as an effect of financial deregulation.

This impressive study goes a long way to analyze and establish the liability of foreignness as an important factor shaping the competitiveness and survival of foreign subsidiaries. Revisiting the data it is clear however that the overall difference in exit rates is small: the exit rate is 42,1 per cent (710/1700)for foreign trading rooms against 41,8 percent (407/967)for 
domestic trading rooms. In fact the data indicates a reversal in relative survival rates after year 15 to the advantage of the foreign trading rooms. The comparative long run survival is still open to question, therefore. Moreover, while currency trading is a great industry for isolating the liability of foreignness, it clearly supplies a highly standardized commodity for which ownership advantages may be less easy to establish and defend than in more opaque and innovative businesses. It is not clear, therefore, that findings from this industry generalize to manufacturing industries like pharmaceuticals, chemicals or electronics which harbor the generic multinational companies.

Thomsen (2000) studied foreign subsidiaries in Denmark (1895-1995), which had lower survival probability than a control group composed of the largest domestically owned manufacturing companies. The difference was significant and robust to control for size and industry effects, but not capital structure. Domestically owned companies had higher equity reserves (equity/assets ratios), which had a positive impact on survival. For given equity asset ratios there were no significant survival differences. A main contribution of this study is to point to differences in corporate governance as a possible source of differential survival and the use of capital structure as a proxy for these differences. In addition the long time span is particularly interesting raising the the prospect that multinational ownership may have an adverse long run effect. We therefore build on this unique dataset in the present paper. However, we believe that comparing foreign subsidiaries with the largest domestic manufacturing companies may not be the best research strategy given the heterogeneity of the two samples. We therefore collected another control group matched by size and industry.

Mata and Portugal (2002) compared the survival of newly established firms in Portugal over the period 1983-1989. The 613 foreign-owned entrants had higher survival rates than a control group of domestically-owned companies, but the survival differential disappeared when controlling for workforce education, firm size, legal structure, age and industry variables (growth, entry barriers, concentration etc.). These results for new entries are particulary interesting given that Zaheer and Mosakowski argued that new foreign entrants suffer from a liability of foreignness distinct from the liability of newness (Hannan and Carroll 1992, Stinchcombe, 1965). Their data did not allow them to trace subsequent long-term survival rates of foreign subsidiaries which could be be higher if the liability of foreignness is reduced 
with the age of the company. Moreover, the application to a non-US setting is interesting because smaller national markets like Portugal presumably are less strategically important, i.e. carry a smaller option value in the sense of Kogut and Kulatilaka (1994)

Related literature has provided additional evidence on the liability of foreignness. Miller and Parkhe(2002) measured it by x-efficiency (failure to reach the production possibility frontier) and found higher x-inefficiency in foreign-owned banks. Mezias (2002) found that foreign subsidiaries in the US face more labor lawsuits than domestic firms. In contrast, Nachum (2003) found higher rates of return among foreign financial firms in the city of London. She attributed this to advantages of multinationality in international financial services, particularly lower information costs, and a lack of home based advantages. Brannen (2004) found foreignness to be a liability for Disneyland Paris, but an advantage for Disneyland Tokyo.

Overall, the relative survival of foreign subsidiaries is theoretically determined by a balance of benefits and costs of foreignness. The classical literature on multinational enterprises tends to focus on the benefits which is quite natural given that its prime goal is to explain the massive increase in the volume and stock of foreign direct investment over the past decades (Caves, 1996). Despite an improved understanding of the costs of foreignness we see no compelling reason to deviate from the a priori assumption of a multinational performance advantage in the present paper. On the contrary, we will argue that multinational companies posses an important real option compared to domestic companies: the option not to invest (a defer option in the sense of Dixit and Pindyck, 1994). We expect multinational companies to weigh the costs and benefits of foreign direct investment in a specific country before they invest and to select only investments for which the expected benefits exceed the costs. This late mover advantage relative to domestic companies (not be confused with a first mover advantage relative to other subsidiaries) is a consequence of the observation (verified in the following) that multinationals tend to enter after domestic companies.

Admittedly, it is possible to this of exceptions to this scenario. For example it may be that foreign companies have to establish subsidiaries despite information disadvantages (ignorance of the host country environment) and so have to accept higher failure risk despite possibly higher expected returns. 
However, the reverse may also very well be true: multinationals may have better knowledge of industry conditions before they invest which would imply lower expected risk of failure. To be sure there may be industries (like currency exchange) in which the advantages of multinationality are smaller, but we expect to see fewer foreign subsidiaries in those very industries. It is even possible that multinational companies overinvest because of agency problems. But even with a limited amount of capital market efficiency overinvestment of this kind is unlikely to persist over very long periods of time such as (in this case) a century.

We therefore propose what we believe to be the classical a priory hypothesis for empirical testing:

Hypothesis 1. Foreign subsidiaries are likely to have a higher survival probability than domestically owned companies.

However we expect this main effect to be moderated by a number of variables that influence the balance of costs and benefits of foreignness.

Company size effects are emphasized by Caves (1998). Jovanovic (1982) and Aggarwal and Gort (1999) present theoretical arguments for a positive size effect on survival because of efficiency and selection effects (Jovanovic 1982), a larger investment commitment (Caves 1998), higher sunk costs (Aggarwal and Gort 1999) and lower sensitivity to risk and large shocks (Hannah 1999). Empirical support for a positive effect of company size on survival is found by Mata et al. (1995), Audretch and Mahmood (1995), Caves (1998), Aggarwal and Gort (1999). We control for subsidiary size effects by a matched sample design and test the robustness of our results by including it as control variable. While size is important to both foreign and domestic companies we do not have any strong prediction about the effect of subsidiary size on their relative survival.

However, size effects could also occur at the parent company level. In general the multinational parent companies of foreign subsidiaries in a small nation are likely to be much larger than domestic companies. So if parent company size effects were important, one would expect foreign subsidiaries to have a higher survival frequency. We cannot directly observe parent company size, but we can examine a specific size-related advantage of multinationality 
which is emphasized in the literature: better access to and lower costs of capital. We would expect this to show up in a lower risk of bankruptcy (c.f. Li and Guisinger 1991), which of course only occurs when a corporation is unable to repay its debt. Admittedly, it is legally possible for foreign parent companies to hide behind "the veil of the corporation" and let subsidiaries in foreign countries go bankrupt (Ferran, 1998). But we believe that there are immaterial costs of bankruptcy (e.g. reputation risks) which make them choose bankruptcy as a last resort. For example, bankruptcy may damage the brand name of the parent company and so create barriers to sales and marketing in the future. Moreover bad reputation may spill over to over host countries and increase the costs of doing business there.

Industry effects are emphasized by Aggarwal and Gort (1999). Theoretically, industry effects can be caused by a number of factors. The level of competition, the predictability of demand and the rate and form of technological change all vary across industries and affect the probability of survival (Aggarwal and Gort 1999 p. 3). Industries may be at different stages of the industry life cycle (Jovanovic and MacDonald 1994, Klepper 1996) with low survival rates in shake-out periods (early and later). Generally, high-tech industries may have higher rates of technological obsolescence (Aggarwal and Gort 1999). The theory of the multinational enterprise predicts that the frequency of foreign subsidiaries is higher in industries characterized by ownership, location and internalization advantages (Dunning 1981). Empirically, several studies find that multinational subsidiaries do tend to cluster in certain industries (e.g. Caves, 1988, Thomsen and Pedersen 1998). A priori we expect foreign subsidiaries to have higher survival rates in these scale and scope intensive industries with first mover and integration advantages (Chandler 1990), whereas their survival rates would tend to be lower in the traditional industries where small-scale production is still the rule and flexibility is a key to success.

Time period. We expect relative survival rates to change substantially over a 100 year period during which there have been large changes in policy regimes, economic conditions and technology which are known to have influenced trade policies (e.g. protectionism, barriers to international investment) and internationalization. We follow Geoffrey Jones (2005 p. 20) in distinguishing between different periods in the history of multinational enterprise. Phase one "the first global economy" covers the period 1880-1929, that is the 
free trade period prior to 1914 and the continuing liberal trade regime in the 1920s. Phase 2 "disintegration" covers the years of protectionism and war 1930-150 and the beginnings of the new global economy 1950-1979. Phase 3 is the new global economy 1979- and on.

Abstracting from these enormous policy shocks, there may be a downward trend in the liability of foreignness as a consequence of better access to information, reduced language barriers, lower transportation costs, more efficient distribution channels and the like. However, the advantages of foreignness have probably also been affected. Increasing internationalization of domestic firms and competition among foreign subsidiaries could also mean that advantages of foreign ownership are reduced over time. For example, it has to an increasing extent become possible to service a host country market by exporting from a subsidiary in another country.

Company Age is likely to influence learning (information costs) and reputation (legitimacy). If foreign companies are by definition late movers, their survival chances could be negatively affected. However, as with size, the age and experience of the parent company may be important as well. Following Zaheer and Mosakowski (1997) we expect the relative survival of foreign companies to increase with subsidiary age as they learn more about their new environment and become more integrated in host country networks.

Other variables. A number of other variables are likely to influence firm survival. Variables like knowledge stock, R\&D intensity, brand capital etc. could influence survival rates, but cannot be measured empirically over a long period of time. Instead we rely on a twin study (matched sample) methodology: by matching foreign subsidiaries with companies in the same industry and size class and studying their relative survival we hope to control for unobservable heterogeneity and to be able to identify the effects of foreign ownership.

\section{Sampling method}

This paper uses the data set on foreign subsidiaries gathered by Thomsen (2000), but instead of comparing them to the largest domestically owned 
manufacturing companies we collected a matched sample based on industry and company size. In addition to an improved methodology we updated the data set by a follow up study in 2001. We were also able to add information on the causes of exit in the last part of the period.

Denmark is a small European country (EU member) of 5 million people (comparable to Minnesota) and a per capita gross national income of 40650 US dollars compared to US average 41400 US dollars (World Bank, 2005). Despite a large welfare state the level of government intervention in the privat sector is very limited and the economy is very open to international trade and investment (Exports constitute some 45Export.Gov (the US government export portal) describes the Nordic region (Denmark, Finland, Norway and Sweden) as "an attractive and lucrative market for U.S. companies, as well as an important trading partner to the United States. Its 24 million consumers are looking for high-quality and reputable products from abroad, and are receptive to U.S. products and services. ... The Nordic countries are among the world's wealthiest countries. The region is dynamic, highly sophisticated and very competitive, with stable political and economic climate. English is widely spoken and commonly used in the business environment making the market easy to enter for U.S. companies. American high quality products and services as well as state-of-the-art technology are well received."

The data set for this paper covers the period 1895 to 2001 and is based on a Danish company register (Greens Danske Fonds og Aktier) which has been published since 1887 and covers a broad range of companies operating in Denmark, though with a clear focus on joint stock companies, particularly the larger ones, and with improved coverage over time. The sampling design is as follows: All foreign-owned manufacturing companies registered in the years 1895, 1907, 1915, 1925, 1934, 1946, 1956, 1964, 1975, 1985, 1995 were sampled. Based on registered share capital and industry we found a matching domestic company recorded in the registry in the same year. Hereby, 533 foreign-owned and 528 matching domestic-owned companies were identified. In this way our database consists of 528 pairs of companies which at entry were matched on industry and share capital as closely as possible.

For example, of the more well known international companies, we match Kodak with a local producer (Nordisk Kamerafabrik) which turned out to exit quickly (just one observation in 1915), whereas Kodak Denmark is still 


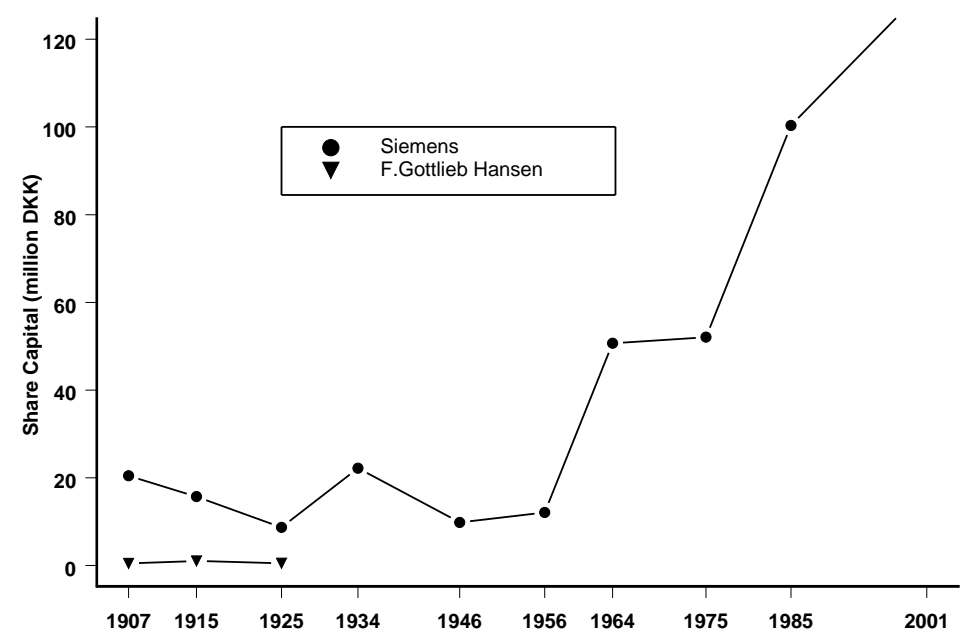

Figure 1: Inflation Adjusted Share Capital for Siemens and the Danish Control Firm.

active today. American Tobacco Company (entry 1901) is matched with the Danish Cigar and Tobacco Factories (now Scandinavian Tobacco). Contrary to the general trend this company outlived American Tobacco despite the lack of domestic tobacco production (eventually the Danish company acquired its competitor). United Shoe Machinery Company (entry 1909, exit after 1956) was matched with Julius Larsen Footwear Machinery (which exited during the depression following 1929). Citroen (entry with distribution only in 1924) was matched with a domestic distribution company (Scandinavian Motor).

The evolution of Siemens and its match is given in Figure 1 to illustrate the approach. Note that the match is not perfect since Siemens is somewhat larger than the control company. Over time Siemens has expanded steadily (even despite general expropriation policies after the second world war when Denmark was liberated from German Occupation), while the control company exited already in the 1930s. 
The general pattern is that many of the foreign subsidiaries have been in Denmark for almost a century. This is true of Asea (entry 1925) Dunlop (1914), Gilette (1919), Goodyear (1925), Philips (also 1925). There can be no doubt that these companies have significant staying power.

There have been two major waves in the establishment of foreign subsidiaries in Denmark, 1915-34 and 1964-1995. In particular, there was a virtual explosion of subsidiary creation during the 1970s and 1980s. The majority (84.5\%) of the companies enter the study after 1970.

After entering the database the companies were tracked in each of the above sampling years with a follow-up in 2001. We recorded the evolution of the company in terms of share capital, assets, industry, and if possible the actual year of exit. The company register also provided information on establishment year and thereby company age.

The ability to track companies over a century is a major advantage of our study compared to previous research, but it does imply certain limitations on data availability, particularly early in the period. For example, we may be able to observe that a certain company is active at some point in time, but has disappeared in the next period without knowing precisely what happened to it. Naturally, we cross-checked our data source for possible name changes, mistaken omissions, information about mergers etc., but in some cases we were unable to verify what happened. Our "exit" event therefore is not synonymous with "liquidation" or death, but includes exit by merger into a larger entity (if the company disappears as an independent unit). Moreover, although we did try to account for this, a company may in some cases survive as a corporate entity (owning property or a bank account) while actual business operations have ceased.

Secondly, the available accounting information is in some cases limited, particularly for smaller companies early in the period. At the minimum we have access to year of establishment, industry and share capital. 


\section{Descriptive statistics}

A first look at the data, without taking the matching or the external variables into account, indicates a marginally higher exit risk for domestic companies (Table 1). At the end of follow-up period 356 (67\%) domestic companies and $389(74 \%)$ foreign subsidiaries were still operating while the remaining 172 (33\%) domestic and 139 (26\%) foreign subsidiaries had ceased their activities before 2001. In other words, at first glance the exit rates seem to be lower for the foreign subsidiaries and foreign firms seem have higher survival power in support of hypothesis 1.

\begin{tabular}{|l|c|c|c|}
\hline Ownership & No. of exits & No. of survivors & Total \\
\hline Domestic & $172(32.6 \%)$ & $356(67.4 \%)$ & $528(100 \%)$ \\
Foreign & $139(26.3 \%)$ & $389(73.7 \%)$ & $528(100 \%)$ \\
\hline Total & $311(29.5 \%)$ & $745(70.5 \%)$ & $1056(100 \%)$ \\
\hline
\end{tabular}

Table 1. Exit rates for domestically owned and foreign subsidiaries

In table 2 we break down the exits by type. Overall, the differences seem small. For example, the fraction of foreign and domestic firms exiting by mergers and acquisitions is identical. However, the bankruptcy frequency though as low as a few percent for both kinds of firms - is 4 times higher for domestically owned firms (3.97\%) than for foreign subsidiaries $(0.95 \%)$. Apparently, foreign parent companies prefer to avoid bankruptcies and have the financial strength to carry on.

\begin{tabular}{|l|rr|rr|rr|}
\hline Cause & \multicolumn{2}{|c|}{ Domestic } & \multicolumn{2}{c|}{ Foreign } & \multicolumn{2}{c|}{ Total } \\
\hline Merger etc & 57 & $(10.8 \%)$ & 57 & $(10.8 \%)$ & 114 & $(10.8 \%)$ \\
Liquidated & 12 & $(2.3 \%)$ & 11 & $(2.1 \%)$ & 23 & $(2.2 \%)$ \\
Bankrupted & 21 & $(4.0 \%)$ & 5 & $(0.9 \%)$ & 26 & $(2.5 \%)$ \\
Empty & 9 & $(1.7 \%)$ & 5 & $(0.9 \%)$ & 14 & $(1.3 \%)$ \\
Unknown & 73 & $(13.8 \%)$ & 61 & $(11.6 \%)$ & 134 & $(12.7 \%)$ \\
Censored & 356 & $(67.4 \%)$ & 389 & $(73.7 \%)$ & 745 & $(70.5 \%)$ \\
\hline Total & $528(100.0 \%)$ & 528 & $(100.0 \%)$ & $1056(100.0 \%)$ \\
\hline
\end{tabular}

Table 2. Exit causes for domestically owned companies and foreign subsidiaries 
The matching strategy succeeded with respect to industries. Table 3 demonstrates that food, chemicals and metal products are the main industries in which foreign subsidiaries are active. This agrees with previous studies (Caves, 1996, Chandler 1988) which find that multinationals are particularly active in industries characterized by (multi-firm) economies of scale and scope.

\begin{tabular}{|l|l|c|}
\hline $\begin{array}{l}\text { Industry } \\
\text { code }\end{array}$ & Main Industry & $\begin{array}{c}\text { No. of } \\
\text { Companies }\end{array}$ \\
\hline 31 & Food, drink, tobacco & $59(11.2 \%)$ \\
\hline 32 & Textiles & $12(2.3 \%)$ \\
\hline 33 & Wood, furniture & $11(2.1 \%)$ \\
\hline 34 & Paper, printing, publishing & $28(5.3 \%)$ \\
\hline 35 & Chemicals & $130(24.6 \%)$ \\
\hline 36 & Materials (glass, concrete, ceramics) & $12(2.3 \%)$ \\
\hline 37 & Minerals & $6(1.1 \%)$ \\
\hline 38 & Metals, Machinery, Electrical products & $244(46.2 \%)$ \\
\hline 39 & Other manufacturing & $26(4.6 \%)$ \\
\hline Total & & $528(100 \%)$ \\
\hline \hline
\end{tabular}

Table 3. The paired sample by main industry.

Our preferred size measure is share capital. This is both because it is always available and because of endogeneity problems with measures that reflect the relative success of the company. Companies that are not competitive are more likely to experience cutbacks and size reductions and then to exit, but it would be wrong to interpret this a negative effect of company size on exit rates. In contrast the (inflation adjusted) share capital reflects the size of the funds that are ex ante invested in the company before its relative fitness is tested in practice.

It was not possible to find exact matches according to company size capital, but as seen in Figure 2, the overall picture is that the share capital roughly coincides for matched companies. 


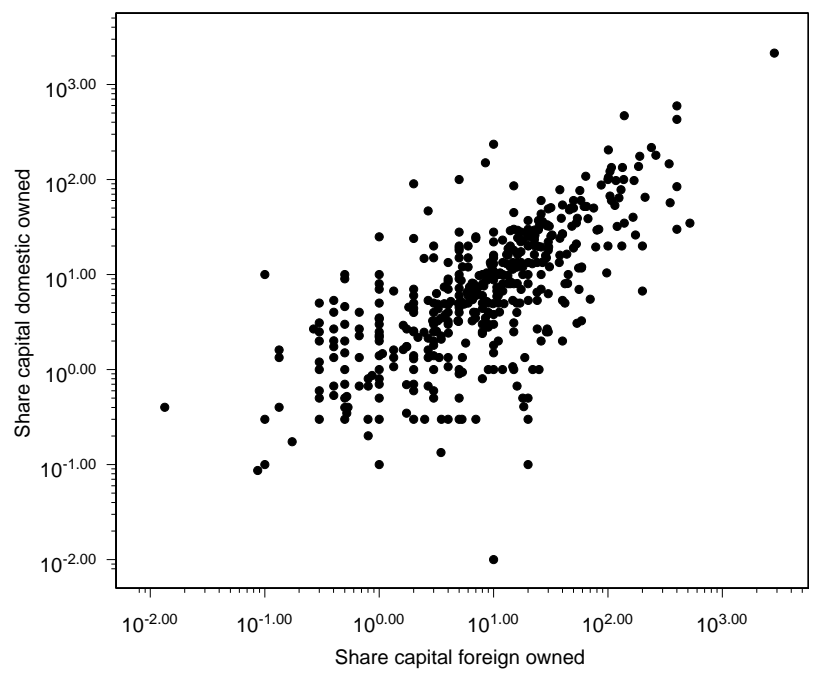

Figure 2: Share capital at entry - logarithmic scale.

\section{Statistical Methods}

The statistical analyses are based on the proportional hazards model for analysis of censored survival data as proposed by Cox $(1972,1975)$. Differently from the 'standard' proportional hazards model companies do not enter the study at the same age, and to avoid problems with length biased sampling, each company only contributes to the partial likelihood from the age of entering into the study - that is, the observations are considered as left truncated.

To account for the matched design a stratified proportional hazards model is used (see eg. Kalbfleisch and Prentice, 1980, 2002). In this model, the hazard function $\lambda_{i j}(t)$ for the i'th company (domestic and foreign, respectively) in the $j$ 'th pair of companies is specified according to the proportional hazards model, such that

$$
\lambda_{i j}(t)=\lambda_{0 j}(t) e^{\beta^{\prime} X_{i j}}, \quad i=1,2, j=1, . ., N,
$$

where $\lambda_{0 j}(t)$ 's are the unknown baseline hazard for the j'th pair of companies. $X_{i j}$ is the vector of covariates and $\beta$ the unknown regression parameters. 
Alternatively, the model can be formulated as

$$
\lambda_{1 j}(t)=\lambda_{2 j}(t) e^{\beta^{\prime}\left(X_{1 j}-X_{2 j}\right)}, \quad j=1, \ldots, N
$$

Results will be given in terms of relative risks of exit for domestic compared to foreign companies, $\frac{\lambda_{1 j}(t)}{\lambda_{2 j}(t)}=\exp \left(\beta^{\prime}\left(X_{1 j}-X_{2 j}\right)\right)$. A relative risk larger than one means that the risk of exit is larger for domestic owned companies than for foreign subsidiaries. The tests for matched pairs rely on intrapair comparisons alone. Only pairs of companies where one of the companies close down before either closing or censoring of the other contributes to the test statistics and consequently the effective sample size can occasionally be small. Accordingly, the precision of the estimated coefficients may be weakened as well as the power of hypothesis tests.

Within the above model it is not possible to estimate effects of covariates with constant values within matched pairs of companies (nested effects). However, it is possible to calculate test statistics for comparison of relative risks for groups of pairs by including interaction terms and hereby evaluating the influence of e.g. year of entry and industry. For this purpose we have used likelihood-ratio test statistics, -2logLR, which are evaluated in the approximating $\chi^{2}$ distribution.

\section{Results}

The standard marginal Kaplan-Meier survival curves for both categories are seen in Figure 3, which portrays the estimated survival probability as a function of firm age. The two ownership categories seem to have very similar survival rates for the first 20 years of age but foreign subsidiaries have greater staying power between 20 and 100 years of age. This is contrary to the idea that domestic companies have an advantage in the first period because of greater familiarity with the institutional environment. But higher survival rates for older international firms could indicate that the costs of foreignness decrease with the age and experience of the company. It has to be stressed, however, that due to the matched design, the survival curve drawn for the domestic firms not is representative for the entire population of domestic companies. 


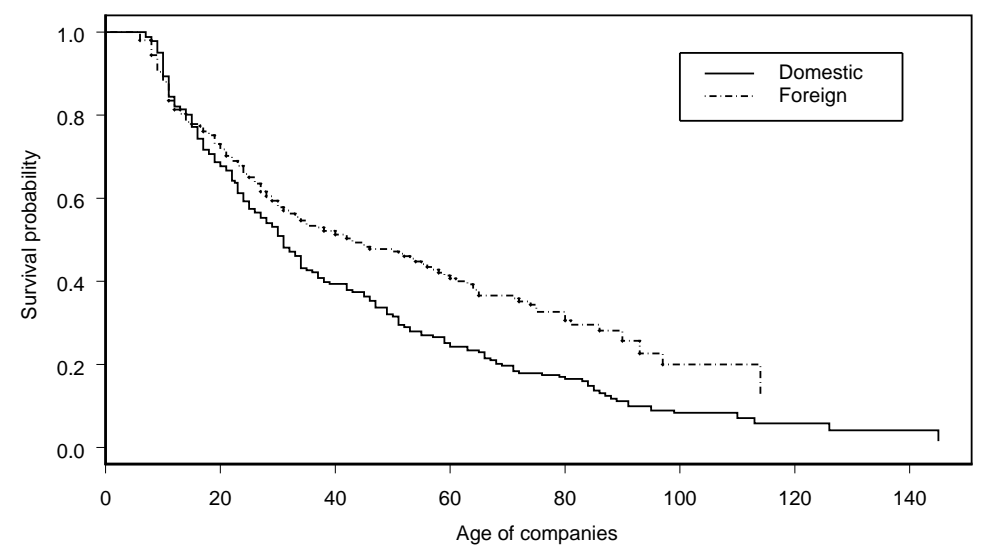

Figure 3: Marginal Kaplan-Meier survival curves for domestically owned companies and foreign subsidiaries

Overall, the domestic companies have a higher exit risk. The estimated relative risk is 1.52 (95\% confidence limits: $(1.21,1.90)$ ), and the usual score test for comparison of the two survival curves results in a test statistic equal to 13.4 which with one degree of freedom corresponds to $\mathrm{p}=0.02 \%$. However, neither the above estimate of the relative risk nor the test statistic utilize the matched design.

Taking the matching into account by applying model (1) the overall relative risk of exit is increased to 2.31 (95\% confidence limits: $(1.56,3.44)$ ) and the score test becomes highly significant, $\mathrm{p}<0.00 \%$ (see Table 5). The wide confidence limits for the relative risk are attributable to the fact that the 'effective' sample size when analyzing the stratified model is reduced to 246 pairs of companies with at least one exit. 


\begin{tabular}{|c|c|c|c|}
\hline & $\begin{array}{r}\text { Analysis } \\
\text { Overall co }\end{array}$ & $\begin{array}{l}\text { of Model (1) } \\
\text { nparison of risk }\end{array}$ & \\
\hline & No. of pairs & $\begin{array}{l}-2 \log L R \text { test, } \\
\text { df, } \mathbf{p} \text {-value }\end{array}$ & $\begin{array}{c}\text { Relative Risk } \\
(95 \% \text { confidence limits })\end{array}$ \\
\hline Foreign vs domestic & $528(246)$ & $18.8,1,<\mathbf{0 . 0 0 \%}$ & $\mathbf{2 . 3 1}(1.56, \quad 3.44)$ \\
\hline \multicolumn{4}{|c|}{ Comparison of risk within groups } \\
\hline $\begin{array}{c}\text { Main Industry } \\
\text { Food }\end{array}$ & & & \\
\hline $\begin{array}{l}\text { Food } \\
\text { Chemical }\end{array}$ & $\begin{aligned} 59 & (31) \\
130 & (64)\end{aligned}$ & $\begin{array}{l}0.09,1, \mathbf{7 6 . 3 \%} \\
11.6,1, \quad \mathbf{0 . 1 \%}\end{array}$ & $\begin{array}{ll}\mathbf{1 . 2 0} & (0.21,0.77) \\
\mathbf{4 . 0 0} & (1.64,9.81)\end{array}$ \\
\hline Metal & $244(113)$ & $10.9,1, \quad \mathbf{0 . 1 \%}$ & $2.47(1.41,4.33)$ \\
\hline Other & $95 \quad(38)$ & $0.25,1, \mathbf{6 1 . 7 \%}$ & $1.29(0.28,5.91)$ \\
\hline \multicolumn{4}{|l|}{ Year of Entry } \\
\hline 1895-1925 & $42 \quad(38)$ & $4.08,1, \quad \mathbf{4 . 4 \%}$ & $2.0(1.00,4.00)$ \\
\hline $1934-1956$ & $33 \quad(28)$ & $18.3,1, \quad \mathbf{0 . 0 \%}$ & $10.5(2.45,44.7)$ \\
\hline 1964-1975 & $58 \quad(39)$ & $4.44,1, \quad 3.5 \%$ & $2.8(1.01,7.78)$ \\
\hline 1985 & $107 \quad(51)$ & $1.84,1, \mathbf{1 7 . 5 \%}$ & $1.7(0.78,3.71)$ \\
\hline 1995 & $288 \quad(90)$ & $0.09,1, \mathbf{7 6 . 3 \%}$ & $\mathbf{0 . 8 3}(0.25,2.73)$ \\
\hline \multicolumn{4}{|l|}{ Calendar-period } \\
\hline 1895-1929 & $42 \quad(7)$ & $3.96,1, \quad \mathbf{4 . 6 \%}$ & $6.00 \quad(0.72,49.7)$ \\
\hline 1930-1949 & $60 \quad(27)$ & $9.64,1, \quad \mathbf{0 . 2 \%}$ & $4.48 \quad(1.62,13.2)$ \\
\hline 1950-1969 & $53 \quad(9)$ & $2.09,1, \mathbf{1 4 . 8 \%}$ & $(0.91,22.2)$ \\
\hline $1970-2001$ & $484(203)$ & $6.13,1, \quad \mathbf{1 . 3 \%}$ & $1.81 \quad(1.12,2.92)$ \\
\hline \multicolumn{4}{|c|}{$\begin{array}{l}\text { Test statistics and p-values for } \\
\text { influence on relative risks }\end{array}$} \\
\hline Share Capital & & $0.37,1, \mathbf{5 4 . 3 \%}$ & \\
\hline Main Industry & & $4.09,3, \mathbf{2 5 . 2 \%}$ & \\
\hline Year of Entry & & $10.0,4, \quad \mathbf{4 . 0 \%}$ & \\
\hline Calendar-period & & $10.4,3, \quad \mathbf{1 . 6 \%}$ & \\
\hline
\end{tabular}

Table 4. No. of pairs of companies and (in brackets) pairs with at least one exit, likelihood ratio test statistics (-2logLR), degrees of freedom (df) and corresponding significance values for comparison of exit risks for domestically owned companies and foreign subsidiaries by use of model (1). Further, the estimated relative exit risk (domestic/foreign) is shown together with the estimated $95 \%$ confidence limits. 
The results of estimates by model (1) are seen in Table 4. Analysis of models with simultaneous inclusion of several factors are in general not reported, but is limited to few relevant cases, as the effective sample size in general is too small to perform reliable estimates and test statistics. As seen from the table, analysis of possible interaction between firm size and ownership showed no significant effect of firm size measured by the logs of the inflation-adjusted share capital, $\mathrm{p}=54.3 \%$. Further, the relative risk of exit for domestic compared to foreign companies was studied within industry groups. Given the matched design and the relatively small effective number of companies, the analysis of differences between industry groups was performed on aggregated industry level (Table 5). It appears that exit rates for domestic owned companies are higher in the chemical industries (estimated relative risk of 4) and metal industries (estimated relative risk 2.47) than in food and other industries. However, the differences are not statistically significant $(\mathrm{p}=25.2 \%)$. The size effect (of inflation-adjusted share capital) also turned out to be insignificant within the main industries $(-2 \log L R=3.90$, $\mathrm{df}=3, \mathrm{p}=72.8 \%$ ).

Next, in the same table, we report the relative risk as a function of year of entry. We find a bell-shaped curve over the last century. From a value of 2.0 on average for the first 3 decades, domestic relative exit risk increased to around 10 in the 1930s-1950s, but has since dropped steadily to a point where domestic firms now have lower exit risk than foreign companies (relative exit risk). The overall differences in relative risks between calendar periods was found to be slightly significant, $\mathrm{p}=4.0 \%$. A likely explanation is that the exit rate is a function of the level of entry by foreign subsidiaries, which was quite high in the period before the first world war, but then decreased in the interwar period as function of protectionism during the 1930s, the war economy (1940s) and the subsequent rationing period (1950s). Since globalization has not progressed continuously over the last century, the relative exit has evolved with the economic fundamentals rather than the time trend.

As also seen in Table 4 foreign companies which enter in recent years (1985 and 1995) do not have significantly higher survival rates than domestic companies, whereas foreign companies entering earlier had significantly higher survival rates than domestic companies.

To examine potential calendar time effects, the relative risk was esti- 
mated within four time-periods. In each period, the risk-set consists of pairs of companies where both are active in the beginning of the calendar-period and those surviving the calendar period are considered censored at the end of the period. In this way some companies may be in the risk set for several periods. However, the estimates of the relative risks are not affected by pairs of companies where both survive a given calendar-time period and consequently it is possible to compare the calendar specific relative risks. As seen in Table 5 the calendar specific relative risks are found to differ significantly, $(\mathrm{p}=1.6 \%)$. Due to the low effective number of pairs of companies the estimated precision of the relative risks is low, specially in the periods '18951929' and '1950-1969' and these have to be interpreted cautiously. However, there is a clear tendency to smaller differences in exit risk of foreign versus domestic companies. In '1970-2001' the relative risk has dropped to 1.81 $(1.12,2.92)$. In this period, neither differences in inflation-adjusted share capital nor main industry have a significant influence on survival after adjusting for ownership (Share capital: $-2 \log L R=0.028$, $\mathrm{df}=1, \mathrm{p}=86.6 \%$; Main industry: $-2 \log L R=0.324, \mathrm{df}=3, \mathrm{p}=95.5 \%$ ).

Due to the low precision in ' 1895-1929' and ' 1950-1969' comparison of the periods has been restricted to '1930-1949' and '1970-2001'. Comparison of the relative risks in these two periods shows that the difference is insignificant $(-2 \log \mathrm{LR}=2.56, \mathrm{df}=1, \mathrm{p}=10.9 \%)$. However, as seen in Figure 4. domestic companies tend to exit more rapidly than foreign subsidiaries in the inter- and after-war period, while the relative risk is much lower in more recent years.

Excluding bankruptcies from the analysis does not qualitatively alter the results. The overall relative exit risk decreases to $2.12(1.37,3.12)$ and is still significantly different from one $(\mathrm{p}=0.03 \%)$. Similarly to the analyses based on the full data set, neither Share capital nor Main industry have a significant influence on the relative exit risk, whereas both Year of entry and Calendar-period affects the relative exit risks significantly. The general picture of the estimated relative risks within groups are almost unaltered, but the estimated risk ratios are slightly lowered. 

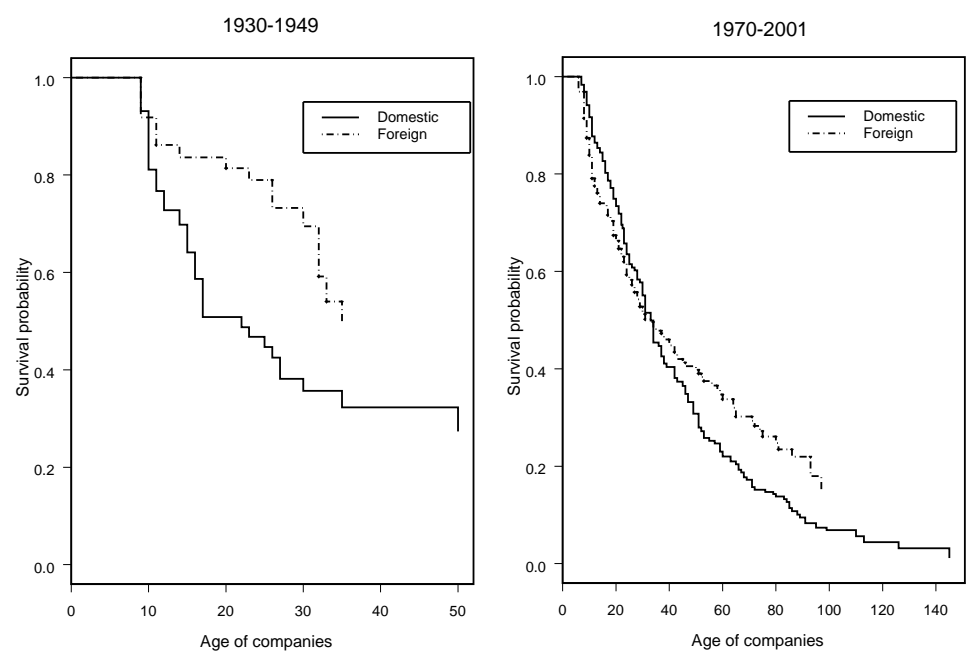

Figure 4: Kaplan-Meier survival curves for domestic- resp. foreign-owned companies in time periods '1930-1949' and '1950-1969' respectively.

\section{$7 \quad$ Discussion}

To sum up, we find that domestic companies have a significantly higher exit rate than foreign subsidiaries. Thus our main hypothesis is supported. The overall estimate of the relative risk of exit is 2.31 in favor of foreign subsidiaries. Apparently, the benefits of foreign ownership including access to capital, brands, knowledge and other resources from the parent company outweigh the costs of foreignness. However, the foreign survival advantage decreases over time and becomes insignificant at the end of period which seems to imply that the gains to foreignness have been eroded over time (as also observed by Nachum, 2003). Since the decreasing survival premium coincides with an increase in the number of foreign subsidiaries, one possible explanation seems to be that increasing competition among foreign subsidiaries and a more internationally competitive domestic sector have gradually reduced the comparative advantage of foreign firms. This is also consistent with particularly high relative survival rates for the relatively few foreign subsidiaries which entered in the protectionist period period 1934-1956. 
Compared to previous work our study differs by taking a long run perspective, by the twin study methodology and by examining a small country setting. Because of the long-run nature of the dataset we are able to document that the relative survival of foreign subsidiaries is dependent on the historical context and not just in the intuitive way that more international openness implies better survival.

Since we find insignificant differences at the end of the period, our results are consistent with Mata and Portugal (2002), who also examined a small country setting and found no survival differences between foreign and domestic companies after controlling for the influence of other relevant variables. Like Mata and Portugal we find no significant survival differences in the first decade after entry.

Compared to Zaheer and Mosakowski(1997) we find no indication that the foreign subsidiaries in our sample start off with a liability of foreignness, but as indicated we do find that their survival chances improve the older they get, for example because of learning and increasing legitimacy in the host country environment. Some of them appear to have become regular pillars of society with greater seniority than most domestic firms. We conjecture that the sample industry - currency trading - used by Zaheer and Mosakowski(1997)is ideal for isolating the effects of the liability of foreignness because of the standardized and transparent nature of the product, but tends to neutralize firm specific advantages, which bring about the classical ownership and internalization advantages of multinational companies.

Compared to Thomsen (2000), who found a negative survival effect of foreign ownership, we find the opposite result. We attribute the difference to the choice of control group. Thomsen compares foreign companies to the largest Danish manufacturing firms (firms being at least at one point in time included in the top 100). Most likely, the top 100 firms belong to an industrial establishment and are supported by network ties, bank relations or government intervention. Moreover, domestic and foreign companies are not necessarily active or successful in the same industries. As previously noted there is substantial evidence that foreign subsidiaries cluster in certain industries where they are particularly competitive. Domestic companies do not cluster in the same industries, which is probably no accident. First, national clusters reflect the national resource mix and its historical develop- 
ment. Secondly, it is not unlikely that competition from foreign firms will have a negative impact on the number of domestic firms and their survival. Thus the control group that we selected is by design not representative of the domestic firms in general. In other words, we intentionally select companies in industries like automobiles, chemicals and electronics in which multinational firms are known to be highly competitive. Therefore, the policy and strategy conclusion is not that foreign ownership is more competitive, nor even more modestly that foreign subsidiaries survive better than domestic companies, but rather that foreign companies are competitive (survive better)in the industries in which they choose to operate. It is not easy for domestic companies to be competitive in global industries.

The limitations of our research are first and foremost that we study a single country, which may not be representative of large strategically important host countries markets. In principle, however, this makes our conclusions stand out more strongly since we would expect foreign subsidiaries to be more tenacious in larger markets. Secondly, the long term nature of our data implies limitations on availability, for example with regard to the nature of exit. Since our study underlines the importance of history we cannot automatically assume that end period information is valid for the entire sample. Third, we compare foreign subsidiaries to domestic companies which tend to be independent entities. Our study is therefore a test of the combined effect of foreignness and corporate "subsidiarity" compared to for example Pennings et al. (1994) who study the effects of foreignness within a sample of subsidiaries. It is possible, therefore, that the survival premium of foreignness which we observe is attributable to the subsidiary status and that that a comparison with domestically owned subsidiaries would lead to different results. However, we maintain that our choice of control group is relevant for the many strategy and policy decisions which involve a choice between foreign ownership by a multinational parent company and continuation of the domestic company as an independent entity. In this case our results are inconsistent which commonly held beliefs that foreign ownership is more like to lead to closures.

The most important strategic implication may be that the survival advantages of foreign subsidiaries have been reduced over time. This does not mean that the age of the multinational company is over or anything as dramatic as that. In fact, some of the reduction is attributable to increasing ability to ser- 
vice the domestic market by subsidiaries in other countries, which may well imply advantages to multinationality. But it does probably imply that the historical advantages foreign direct investment have been eroded over time by increasing competition. It is clear that past successes do not necessarily continue into the future, and this also applies to foreign direct investment. 


\section{References}

Agarwal, Rajshree and Michael Gort. (1999), The Determinants of Firm Survival. Working Paper. Social Science Research Network.

Anderson, Erich and H. Gattignon. (1986), Modes of Foreign Entry:

A Transaction Cost Analysis and Propositions. Journal of International Business Studies, 27(3), 1-26.

Audretsch, David B. and Talat Mahmood. (1995), New firm survival: New results using a hazard function.Review of Economics and Statistics, 76, $97-103$.

Boardman, A., D. Shapiro, and R. Vining. (1996), The Role of Agency Costs in Explaining the Superior Performance of Foreign MNE Subsidiaries. International Business Review, 6(3), 295-317.

Brannen. Mary Yoko (2004). When Mickey Loses Face: Recontextualization, Semantic Fit, and the Semiotics of Foreignness. Academy of Management. The Academy of Management Review, 29(4), 593-616.

Buckley, P.J. and Casson, M.C. (1976) The Future of the Multinational Enterprise, Homes Meier: London.

Kalbfleisch, J.D. and Prentice, R. L. (1980, 2002), The Statistical Analysis of Failure Time Data. Wiley, New York.

Caves, R. (1996), Multinational Enterprise and Economic Analysis. Cambridge University Press, Cambridge, UK.

Caves, Richard E. (1998), Industrial Organization and New Findings on the Turnover and Mobility of Firms. Journal of Economic Literature, 36(4), 1947-82.

Chandler, Alfred. (1990), Scale and Scope. The Dynamics of Industrial Enterprise. A History 1880s-1940s. Cambridge, MA: Harvard University Press.

Chung, C.C., P.W. Beamish. (2005), The impact of institutional reforms on characteristics and survival of foreign subsidiaries in emerging economies. The Journal of Management Studies, 42(1) 35. 
Cox, D. R. (1972), Regression Models and Life Tables, Journal of the Royal Statistical Society Series B, 20, 187 - 220.

Cox, D. R. (1975), Partial Likelihood, Biometrika, 62, 269-276.

Delios, A., and P.W. Beamish. (2001), Survival profitability: The roles of experience and intangible assets in foreign subsidiary performance. Academy of Management Journal, 44(5) 1028.

Delios, A., and P.W. Beamish. (2004), Joint venture performance revisited: Japanese foreign subsidiaries Worldwide1. Management International Review, 44(1), 69.

Dhanaraj, C., P.W. Beamish. (2004), Effect of equity ownership on the survival of international joint ventures. Strategic Management Journal $25(3), 295$.

Dunning. J. (1981), International Production and the Multinational Enterprise. Allen and Unwin. London.

Dutta, Prajit and Roy Radner. (1999), Profit Maximization and the market selection hypothesis. Review of Economic Studies, 66(229), 769-798.

Froot, Kenneth A. ed. (1995), Foreign direct investment. A National Bureau of Economic Research Project Report. University of Chicago Press. Chicago.

Frynas, Jedrzej George, Kamel Mellahi and Geoffrey Allen Pigman. (2006). First mover advantages in international business and firm-specific political resources. Strategic Management Journal, 27(4), 321-345.

Graham, Edward M. and Paul Krugman. (1995), Foreign direct investment. In Froot, Kenneth A. editor. Foreign direct investment. A National Bureau of Economic Research Project Report. University of Chicago Press. Chicago

Greens Danske Fonds og Aktier (a Danish Company register. Now: Greens. Hndbogen om Dansk erhvervsliv). Various years.

Hart, O. 1995. Firms, Contracts and Financial Structure.Oxford University Press. New York. 
Hannah, Leslie. (1999), Marshal's "Trees" and the Global "Forest": Were "Giant Redwoods" Different? In Naomi R. Lamoreaux, Daniel M. G. Raff and Peter Temin, editors. Learning by Doing in Markets, Firms, and Countries. University of Chicago Press. Chicago.

Hannan M, Carroll G. (1992). Dynamics of Organizational Populations. Oxford University Press: Oxford.

Hennart, Jean F.(1991), The Transaction Cost Theory of the Multinational Enterprise. In C. Pitelis and R. Sudgen, editors, The Nature of the Transnational Firm. London: Routledge.

Hymer S. 1960/1976. The International Operations of National Firms: A Study of Direct Investment. MIT Press: Boston, MA.

Jensen, Michael and William Meckling. 1976. Theory of the Firm: Managerial Behavior, Agency Costs, and Ownership Structure. Journal of Financial Economics, 305-360.

Jones, Geoffrey (2005), Multinationals and Global Capitalism: From the Nineteenth to the Twenty-first Century. Oxford University Press. Oxford.

Jovanovich. B. (1982), Selection and the Evolution of Industry. Econometrica. Vol. 50 No. 3.

Jovanovic, B. and MacDonald, G. M. (1994), The Life Cycle of a Competitive Industry. Journal of Political Economy, 102(2).

Klepper, S. (1996), Entry, Exit, Growth and Innovation over The Product Life Cycle. American Economic Review, 86(3).

Kogut, B. and Kulatilaka, (1994), Operating flexibility, global manufacturing and the option value of a multinational network, Management Science, 40, 123-139.

Kostova, Tatiana (1996) Success of the transnational transfer of organizational practices within multinational companies. Ph.D. dissertation, University of Minnesota, United States - Minnesota. 
Kostova, Tatiana, Srilata Zaheer. (1999). Organizational legitimacy under conditions of complexity: The case of the multinational enterprise. Academy of Management. The Academy of Management Review, 24(1), 64-81.

Lieberman, Marvin B., Montgomery, David B.. (1988). First-Mover Advantages. Strategic Management Journal: Special Issue, 9, 41.

Lieberman Marvin B, David B Montgomery. (1998). First-mover (dis)advantages: Retrospective and link with the resource-based view. Strategic Management Journal, 19(12), 1111-1125.

Li, J. (1995), Foreign Entry and survival: Effects of strategic choices on performance in international markets.Strategic Management Journal, 16(5), 333-352.

Li, J.; Guisinger, S. (1991), Comparative Business Failures of ForeignControlled Firms in the United States, Journal of International Business Studies, 22(2), 209-225.

Mezias, John M (2002). Identifying liabilities of foreignness and strategies to minimize their effects: The case of labor lawsuit judgements in the United States. Strategic Management Journal, 23(3), 229-244.

Miller, Stewart R and Arvind Parkhe. (2002). Is there a liability of foreignness in global banking? An empirical test of banks' x-efficiency. Strategic Management Journal, 23(1), 55-75.

Portugal, P. and Guimaraes, P. (1995), The survival of new plants: start up conditions and post-entry evolution. International Journal of Industrial Organization, 13(4), 459-482.

Mata,J,(2000), Closure and divestiture by foreign entrants: The impact of entry and post-entry strategies. Strategic Management Journal, 21(5), 549-562

Mata, J., P. Portugal. (2002), The survival of new domestic and foreignowned firms. Strategic Management Journal, 23(4), 323- 343. 
McCloughan, Patric and Ian Stone.(1998) Life Duration of foreign multinational subsidiaries: Evidence from UK northern manufacturing industry 1970-1993. International Journal of Industrial Organization, 16(6), 719-747.

Mitchell, W., Berhard Yeung and J. Miles Shaver.(1994) Foreign entrant survival and foreign market share: Canadian companies' experience in United States medical sector markets. Strategic Management Journal, 15(7), 555-568.

Nachum, Lilach (2003). Liability of foreignness in global competition? Financial service affiliates in the city of London. Strategic Management Journal, 24(12), 1187.

Pedersen, T. and S. Thomsen (1997), European Patterns of Corporate Ownership. Journal of International Business Studies, 28(4).

Pedersen, T. and Thomsen, S. (1998), Industry and Ownership Structure. International Review of Law and Economics, 18(4), 385-402.

Pennings, J., Barkema, H. and Douma, S. (1994), Organizational Learning and Diversification. Academy of Management Journal, 37(3), 608-640.

Shaver, J. Myles. (1995), The influence of industry growth and foreign entry rate on foreign direct investment survival. Academy of Management Journal, 201-209.

Shaver, J. Myles (1998), Accounting for endogeneity when assessing strategy performance: Does entry mode affect FDI survival? Management Science, 44(4), 571-585.

Shaver, J. Myles, Will Mitchell and Bernhard Yeung. (1992), The effect of own-firm and other-firm experience on foreign direct investment survival in the United States 1987-1992. Strategic Management Journal, 18(10), 811-824.

Stinchcombe A. (1965). Social structures and organizations. In Handbook of Organizations, March J (ed.). Rand McNally: Chicago, IL; 142-193.

Teece, D. J. (1986), Transactions Cost Economics and the Multinational Enterprise: An Assessment. Journal of Economic Behavior and Organization, (7), 21-45. 
Thomsen, S. (2000), Survival of foreign subsidiaries and domestic companies in Danish Manufacturing 1895-1995. The Scandinavian Economic History Review, 48(2).

Zaheer, S. (1995), Overcoming the liability of foreignness. Academy of Management Journal, 38(2), 341-364.

Zaheer, S.and Mosakowski, E. (1997), The Dynamics of the Liability of Foreignness. A global study of Survival in financial services. Strategic Management Journal, 18(6), 439-464 . 